\title{
Elävät kaupunkilaboratoriot: kulttuuritoimijat Tampereen Hiedanrannan uudistajina
}

\author{
Veera Turku, Ari Jokinen \& Pekka Jokinen
}

\begin{abstract}
Urban living lab for the transformative potential of cultural actors in Hiedanranta, Tampere, Finland
\end{abstract}

This paper examines the role of cultural actors in promoting sustainability in an urban living lab (ULL). The case study utilizes thematic analysis on the interviews of cultural actors working in the multi-sectoral, circular-economy oriented Hiedanranta ULL in Tampere. The results of the study show, first, that the cultural sector is not detached from the innovative business and experimentation sector of the ULL. On the contrary, cultural actors advance creative ambience and co-develop experimentations, making them an essential part of the ULL innovation processes. Second, cultural actors promote social and cultural sustainability at the local level, which often stays hidden in the processes of upscaling innovations. Third, the sustainable and transformative potential of cultural actors, within and beyond the ULL is mostly horizontal. The results suggest that the cultural sector, comprising civil society actors, can have a multidimensional effect on ULL development.

Keywords: urban living lab, social innovation, transformative potential, experimentation, Hiedanranta Tampere

\section{JOHDANTO}

Elävät kaupunkilaboratoriot ovat näkyvä esimerkki meneillään olevasta julkishallinnon siirtymästä kohti yhteistyöfoorumeihin perustuvaa hallintaa (platform governance). Kehitys sai Suomessa vauhtia vuosituhannen ensikymmenellä, kun kaupungit ryhtyivät vahvistamaan paikallista luovuutta, osaamista, yhteistyötä ja innovatiivisuutta kaupunkien kehittämisessä (Anttiroiko 2010). Kaupungit hyötyvät siitä, miten elävät kaupunkilaboratoriot yhdistävät verkostoja, saavat liikkeelle yhteistoiminnan resursseja sekä mahdollistavat laajapohjaista innovointia (Ansell \& Miura 2019). Tästä näkökulmasta elävät kaupunkilaboratoriot ovat avoimen innovoinnin verkostoja, joiden avaintoimijat ja tavoitteet vaihtelevat (Leminen ym. 2016). Kaupungin asettamia tyypillisiä tavoitteita ovat kaupungin elinvoiman ja talouden vahvistaminen, kestävä kehitys sekä yhteistoiminta ja kumppanuudet eri osapuolten välillä (Anttiroiko 2016). Isot kaupungit ovat omaksuneet kaupunkilaboratoriot osaksi strategisia tavoitteitaan ja osallistuvat eri tavoin niiden organisoimiseen (Anttiroiko 2016; Leminen ym. 2017). Vielä on liian varhaista sanoa, millä tavoin erilaisille 'alustoille' siirtyvä hallinta lunastaa lupauksensa julkishallinnon uudistajana (Ansell \& Miura 2019). Joka tapauksessa se on jo vienyt kansalaisten toimijuutta yli uuden julkisjohtamisen opin, jossa kansalainen on nähty ennen muuta asiakkaana ja palveluiden räätälöinnin kohteena (Nesti 2018).

Tarkastelemme artikkelissa kaupunkien mahdollisuuksia reagoida tiukentuviin kestävyysvaatimuksiin elävien kaupunkilaboratorioiden avulla. Elävät kaupunkilaboratoriot, joissa paikalliset innovaatiot ja kokeilut mobilisoidaan kestävyystavoitteiden näkökulmasta, tuovat yhteen kaupunkilaisia, yrityksiä ja tutkimuslaitoksia toimimaan yhdessä kaupungin kanssa (Voytenko ym. 2016; Nesti 2018). Elävä kaupunkilaboratorio on samalla sekä alusta että toimintatapa, joka voi edistää urbaania kestävyyttä esimerkiksi tiedon yhteistuotannon keinoin (esim. Bulkeley \& Castán Broto 2013; Anttiroiko 2016; Tuurnas 2016; von Wirth ym. 2019). Elävällä kaupunkilaboratoriolla ei ole yhtä universaalia 
määritelmää, mutta tässä artikkelissa tarkoitamme sillä julkista tilaa tai paikkaa, jossa paikallinen hallinto osallistaa kansalaisia kehittämään kestävyyttä edistäviä toimintoja ja ratkaisuja yhdessä muiden toimijoiden kanssa. Tästä eteenpäin käytämme tekstissä pääosin lyhyempää käsitettä 'kaupunkilaboratorio'.

Ilmastonmuutos on noussut voimallisesti kaupunkien agendalle ja vaikuttaa myös kaupunkilaboratorioiden kehitykseen. Kestävyysajattelun eturintamassa toimivat kaupungit pyrkivät kohti kestävyysmurrosta, joka edellyttää vanhojen käytäntöjen, ajattelutapojen ja infrastruktuurien muuttamista (Bulkeley ym. 2017; Frantzeskaki ym. 2016). Kestävyysmurros kuvaa kokonaisvaltaista siirtymää kohti kestävämpää tulevaisuutta, johon tähtäävä systeeminen muutos on enemmän kuin yksittäisten kestävyysparannusten summa (von Wirth ym. 2019). Kaupungit vahvistavat ilmastopolitiikkaansa kiertotalouden keinoin, ja jotkut niistä määrittelevät itsensä jo 'kiertotalouden kaupungeiksi' (circular city; esim. Williams 2019). Kiertotaloudessa on kysymys nykymallisen lineaaritalouden sulkemisesta kierroiksi ja palveluiksi, joiden avulla tuotteiden ja materiaalien arvoa pystytään säilyttämään taloudessa mahdollisimman pitkään (Korhonen ym. 2018). Tavoitteena on hillitä ilmastonmuutosta, ylikulutusta, hukkaa, jätteiden tuotantoa ja luonnonvarojen käyttöä.

Tietty ongelma voidaan kuitenkin tunnistaa kaupunkilaboratorioiden kehityksessä. Kestävyyden edistäjinä ne painottuvat usein tai jopa kokonaan taloudelliseen, teknologiseen tai ympäristöön liittyvään kestävyyteen, vaikka julkishallinnon yhteistyöfoorumina niiden pitäisi kattaa myös sosiaalisia ja kulttuurisia elämänalueita, kuten erilaisia elämäntapoja ja kulutuksen muotoja. Ongelma kärjistyy kiertotalouden edistämisessä: talouden ja teknologian näkökulmat hallitsevat kiertotalouden kokeiluita, minkä vuoksi kiertotalouden sosiaalisten ja kulttuuristen elementtien kehittäminen ja kansalaisten mobilisoituminen jäävät helposti varjoon (esim. Keblowski ym. 2020; Corvellec ym. 2020; Hobson 2016). Kiertotalousvisioiden kapeus on hyvin pulmallista, sillä kun ymmärrys urbaanin kestävyyden luonteesta kapenee, jää monenlaista kestävyyttä tukevaa toimintaa huomaamatta.

Tampereella sijaitseva Hiedanrannan kaupunkilaboratorio, joka yhdistää eri toimijasektoreita ja tähtää uuden kaupunginosan rakentami- seen, soveltuu erinomaisesti kyseisen ongelman tutkimiseen. Analysoimme Hiedanrannan kaupunkilaboratoriota kaupungin uutena keinona edistää kiertotaloutta ja kestävyysmurrosta. Kaupungit eivät tähän yksin kykene, kuten julkishallinnon tutkimuksessa on tuotu esiin eri näkökulmista (esim. Zeemering 2018; Kettunen ym. 2019; Krause ym. 2019; Ansell \& Miura 2019; Karppi \& Vakkuri 2020). Tällä hetkellä Hiedanranta onkin toimintaympäristö kiertotaloutta edistäville yrityksille, tutkimukselle sekä kansalaistoimijoille, jotka toimivat yhdessä kaupungin kanssa. Vaikka kaupunkilaboratorio nähdään usein osana strategista kaupungin tavoitteiden kokonaisuutta, me tarkastelemme Hiedanrannan kaupunkilaboratorion organisoitumista kansalaistoiminnasta käsin, keskittymällä alueen luoviin kulttuuritoimijoihin. Kulttuuritoimijat ovat Hiedanrannan suurin toimijaryhmä, ja he vaikuttavat selvästi alueen kehitykseen. Heidän toimijuutensa osana kaupunkilaboratorion kokonaisuutta on jäänyt kuitenkin epäselväksi. Tarkastelemme kestävyyden, innovatiivisuuden ja yhteistoiminnan yhdistelyä kaupunkilaboratorioissa erityisesti kansalaisyhteiskunnan kestävyyspotentiaalin käsitteen avulla.

Tutkimustehtävänä selvitämme, miten kaupunkilaboratoriot auttavat julkishallintoa vastaamaan uusiin kestävyyshaasteisiin. Keskitymme tarkastelemaan Hiedanrannan kulttuuritoiminnan kestävyyspotentiaalia seuraavien tutkimuskysymysten avulla: (1) Miten kulttuuritoimijoiden aktiivisuus edistää kaupunkilaboratorion toimintaa ja organisoitumista? (2) Millaista kestävyyttä kulttuuritoimijat tuottavat? Kysymysten asettelu pohjautuu näkemykseemme Hiedanrannan kaupunkilaboratoriosta prosessinomaisena paikkana, jossa toimijoiden vuorovaikutus edistää siirtymää kohti kestävyyttä ja uusia kiertotalouden ratkaisuja. Artikkelilla osallistumme keskusteluun kaupunkilaboratorioista vuorovaikutteisina yhteistyöfoorumeina ja osana kaupunkien kestävyysstrategioita.

\section{HIEDANRANTA KOKEILUNA JA KOKEILUJEN ALUSTANA}

Hiedanrannan kaupunkilaboratorio on paikka innovatiiviselle ja kokeelliselle yritystoiminnalle, tutkimukselle ja kehitykselle, kulttuurille, taiteelle sekä aktiiviselle kansalaisosallistumiselle. Tampereen kaupunki osti Hiedanrannaksi ni- 
metyn entisen sellutehtaan alueen vuonna 2014, ja alueen omistajana se koordinoi paikan kehitystä ja tämänhetkistä toimintaa. Näsijärven poukamassa neljä kilometriä Tampereen keskustasta länteen sijaitseva yli 100 hehtaarin suuruinen alue on kasvavalle kaupungille houkutteleva rakentamiskohde. Alue on voimakkaassa muutoksessa, sillä Tampereen kaupungin suunnitelmissa Hiedanrantaan on tulossa lähes 25000 asukasta ja 10000 työpaikkaa (Ohjelmasuunnitelma 2019). Vaikka alueella ei ole vielä yhtään asukasta, sinne on kaupungin houkuttelemana löytänyt monipuolinen kirjo toimijoita.

Hiedanrannan kehittämisessä noudatetaan kiertotalouden periaatteita. Alueen yrityksiltä odotetaan älykkyyttä, kestävyyttä sekä kiertotaloutta edistävää toimintaa, ja rakentamisella tavoitellaan ympäristövaikutuksiltaan nettopositiivista kaupunginosaa (Ohjelmasuunnitelma 2019). Hiedanrantaa voidaan tarkastella kokeilujen alustana, innovatiivisuuden valjastamisen keinona sekä todellisena ja reaaliaikaisena kaupunkikehittämisen kohteena ja kokeiluna itsessään. Alueella on parhaillaan käynnissä erilaisia kiertotalouden kokeiluja esimerkiksi ravinne- kierron ja vaihtoehtoisten käymälöiden ympärillä, ja ne yhdistävät alueen yrittäjiä, tutkijoita ja Tampereen kaupunkia. Hiedanrannan yritykset kehittävät muun muassa vertikaaliviljelyn, biohiilen käytön ja aurinkosähköteknologian menetelmiä. Alue on myös toimintaympäristö useille oppilaitoksille ja tutkimushankkeille. Kaupunkilaiset ovat päässeet osallistumaan kaupunginosan suunnitteluun sekä esimerkiksi yhteisösaunan ja kelluvan puutarhan kokeiluihin.

Hiedanrannassa on noin 20 kulttuuritoimijaa tai -ryhmää, mikä tekee heistä alueen suurimman toimijajoukon. Luku sisältää alueen kulttuuri- ja harrastusyhdistykset, käsityöläiset, taiteilijat ja kuntouttavaa työtoimintaa järjestävät tahot. Mikäli mukaan otetaan yhdistysten jäsenet ja harrastajat sekä alueen tapahtumajärjestäjät, on toimijoiden määrä helposti parin sadan tienoilla. Kiertotalouden teknisten innovaatioiden ja yritysten ohella kulttuuritoiminnot ovat Hiedanrannan kaupunkilaboratorion toinen kärki ja kaupunkilaisille näkyvin osa uutta kaupunginosaa. Taulukko 1 esittelee alueen toimijaryhmät ja esimerkkejä niihin kuuluvista toimijoista tai hankkeista tutkimuksen ajankohtana.

Taulukko 1. Hiedanrannan toimijakentän yleiskatsaus.

\begin{tabular}{|l|l|}
\hline RYHMÄ & TOIMIJA / HANKE \\
\hline $\begin{array}{l}\text { Julkishallinto } \\
\text { mahdollistajana }\end{array}$ & Tampereen kaupunki \\
\hline $\begin{array}{l}\text { Kansalaisyhteis- } \\
\text { kunnan } \\
\text { toimijoita, } \\
\text { kuten kulttuuri- } \\
\text { toimijoita }\end{array}$ & $\begin{array}{l}\text { Paja: käsityöläisten yhteisössä toimii mm. verhoilija, ompelijoita, kuvataiteilijoita, seppä, } \\
\text { graafikko, muusikko } \\
\text { Pirkanmaan Kaarikoirat ry: rullalautailuyhdistys on rakentanut Hiedanrantaan sisä- sekä } \\
\text { SCK ry: Spraycankontrol -katutaideyhdistys, järjestää kansainvälistä maalaustapahtumaa } \\
\text { Siedanrannassa } \\
\text { Sopimusvuori ry: kuntouttavaa työtoimintaa, kuten kahvilan ylläpitoa } \\
\text { SWÄG ry: kulttuuriyhdistys järjestää tapahtumia ja hallinnoi kulttuurikeskus Kuivaamoa } \\
\text { Tampereen valokuvausseura ry: tuo yhteen tamperelaiset valokuvaharrastajat } \\
\text { Vannetaiteilija: sirkusharrastamisen ja esitysten organisointia }\end{array}$ \\
\hline $\begin{array}{l}\text { Yritystoimijoita } \\
\text { Carbofex Oy: biohiilen valmistus } \\
\text { Evergreen Farm Oy: vertikaaliviljelyn menetelmät } \\
\text { Fintras Oy: led-teknologia } \\
\text { Polar Night Energy Oy: uusiutuvan energian taltioimisen menetelmät } \\
\text { Zipatta: lounasravintola }\end{array}$ \\
\hline $\begin{array}{l}\text { Tutkimuspainot- } \\
\text { teisia kokeiluja } \\
\text { ja yhteistyö- } \\
\text { hankkeita } \\
\text { (mukana usein } \\
\text { yliopisto ja muita } \\
\text { toimijaryhmäläkokeilut: vedettömien ja erottelevien käymälöiden testausta } \\
\text { Nollakuitukokeilut: nollakuidun arvopotentiaalin ja käyttömahdollisuuksien selvittäminen } \\
\text { Orsi-hanke: Kohti ekohyvinvointivaltiota, yhteiskunnallisen vaikuttavuuden orkestrointi } \\
\text {-tutkimushanke } \\
\text { Sauna: yhteiskehittämisen ja osallistumisen kokeilu, jossa rakennettiin yhteisösauna } \\
\text { Skeittilukio: tuleva lukion oppikokonaisuus Hiedanrannassa } \\
\text { Valokoru: yhteistyössä toteutettu maisemallinen valotaideteos }\end{array}$ \\
\hline
\end{tabular}


Hiedanranta on tutkimuskohteena hyvin ajankohtainen, ja se on tarjonnut kaupungin kanssa tehtävälle tutkimukselle lukuisia tarttumapintoja, kuten alueen luontopohjaiset ratkaisut (Särkilahti ym. 2019), kehittämisvision kestävyysnäkymät (Lehtovuori ym. 2016), kaupunkitila innovaatioiden alustana (Anttiroiko 2016), yhteistoiminnan linjautuminen (Ingstrup ym. 2020) sekä kaupunkilaisten osallisuus kaupunkikehittämisessä (Leino \& Puumala 2020; Laine ym. 2017). Alueen kulttuuritoimijoita ei ole nähdäksemme tutkittu kokonaisuutena.

\section{TUTKIMUKSEN TOTEUTUS}

Tarkastelemme Hiedanrannan kehitystä laadullisen tapaustutkimuksen keinoin. Tutkittu ajanjakso alkaa vuodesta 2015, jolloin Tampereen kaupunki avasi Hiedanrannan portit kaupunkilaisille, yrityksille ja kiertotalouden kokeiluille ja jolloin ensimmäiset kulttuuritoimijat asettuivat Hiedanrantaan. Ajanjakso päättyy vuoden 2019 loppuun, jolloin keräsimme haastatteluaineiston. Vuonna 2019 Hiedanrannassa tapahtui paljon, kun Tampereen kaupunki perusti kehitysyhtiön hallinnoimaan aluetta ja sen siirtymistä kohti rakentamisvaihetta. Hiedanrannan toimijoista suuri osa oli jo ehtinyt asettumaan alueelle siellä vietettyjen vuosien aikana, mutta toisaalta heidän tulevaisuutensa Hiedanrannassa oli edelleen auki. Uuden kehitysyhtiön perustaminen tarkoitti jälleen muutoksia totuttuihin työskentelytapoihin sekä toi epävarmuutta tulevasta. Tästä syystä aineiston kerääminen loppuvuonna 2019 kiinnittyy Hiedanrannassa erityisen kiinnostavaan vaiheeseen.

Ensisijaisen tutkimusaineiston muodostavat kymmenen Hiedanrannassa toimivan kulttuuritoimijan teemahaastattelut. Haastateltavina olivat vannetaiteilija, seppä, graafikko, verhoilija, ompelija, kaksi kuvataiteilijaa, tapahtumajärjestäjä, elektronisen musiikin yhdistys SWÄG ry sekä rullalautailuyhdistys Pirkanmaan Kaarikoirat ry. Kaikki haastateltavat olivat työskennelleet alueella vähintään parin vuoden ajan, ja yhdessä he muodostavat kattavan otoksen alueen kulttuuritoimijoista. Lähes kaikki haastattelut järjestettiin Hiedanrannassa haastateltavien toimitiloissa. Tämä toi esiin yhteistoimintaa, joka ei muutoin noussut esiin.
Kaikissa haastatteluissa käytiin läpi samat teemakokonaisuudet: haastateltavan oman toiminnan vaikuttimet, Hiedanrantaan saapuminen ja mielikuvat alueesta, toimintaympäristön ja oman toiminnan muutokset, arki ja yhteistyö alueella sekä siirtymä väliaikaisuudesta pysyvämpään toimintaan. Teemojen välillä liikuttiin joustavasti, ja haastattelut olivat luonteeltaan keskustelevia. Tällä pyrimme antamaan tilaa haastateltavien omille tulkinnoille ja kertomuksille. Haastateltavien kanssa emme puhuneet kaupunkilaboratoriosta ja kestävyyspotentiaalista, vaan lähestyimme aihetta toimijoiden arjen ja toimintaympäristön kautta. Jokaisen haastateltavan kanssa keskustelimme kuitenkin toiminnan tavoitteista ja yhteiskunnallisesta vaikuttavuudesta. Haastatteluaineistoa täydentävät haastattelutilanteissa tehdyt havainnot, kaupungin kahden viranhaltijan haastattelut, alueen suunnitteludokumentit ja muut Hiedanrantaa koskevat dokumentit (yhteensä noin $10 \mathrm{kpl}$ ). Näiden täydentävien aineistojen avulla muodostimme analyysia tukevan näkemyksen Hiedanrannan kaupunkilaboratorion kehityksestä vuosina 2015-2019.

Analysoimme haastatteluaineiston koodaamalla sen teemoihin, joille kaupunkilaboratorioita ja kestävyysinnovaatioita koskeva kirjallisuus antoi käsitteellistä syvyyttä. Nämä teemat olivat toimijasektorien rajat ylittävä yhteistoiminta (suhteessa alueen yritystoimintaan ja innovatiivisiin kokeiluihin), toimijuus kaupunkilaboratoriossa (otetut ja annetut roolit) sekä motivaatiotekijät (kestävyyttä tukevat tavoitteet). Teemoittelun jälkeen tunnistimme aineistossa yhtäläisyyksiä ja eroja, joita erittelimme edelleen suhteessa tutkimuskirjallisuuteen. Kaikki haastateltavat antoivat luvan käyttää haastattelusitaatteja tunnistettavasti, mutta päädyimme kuitenkin anonymisointiin (H1-H10) suojataksemme haastateltavien yksityisyyttä Hiedanrannan jatkuvassa muutoksessa.

\section{TEOREETTINEN VIITEKEHYS}

\section{Kansalaisyhteiskunnan kestävyyspotentiaali}

Kaupunkilaboratorio rakentuu tyypillisesti julkisten ja taloudellisten tavoitteiden yhdistelmäl- 
le, jolle yksityiskohtaisemmat tavoitteet ovat rakentuneet (Baccarne ym. 2014). Yhteiset tavoitteet liittyvät pitkän aikavälin ratkaisuihin, joissa huomioidaan kestävyyden eri osa-alueet. Yhteisten tavoitteiden lisäksi toimijat edistävät myös omia henkilökohtaisia päämääriään. Lemistä ja Westerlundia (2012) mukaillen pidämme toimijoita, toiminnan tavoitteita sekä toiminnan resursseja kaupunkilaboratorion avainelementteinä.

Tarkastelemme Hiedanrannan kaupunkilaboratoriota alhaalta ylöspäin, kansalaisyhteiskunnan näkökulmasta. Kansalaisyhteiskunnan toimijat edistävät innovatiivisuutta omista lähtökohdistaan ja heillä on vallitsevista käytännöistä eriävä näkökulma muutostarpeisiin ja ongelmien ratkaisuun. Tämä voi haastaa valtavirtaista ajattelua. (von Wirth ym. 2019.) Toisaalta kansalaisyhteiskunnan toimijat ovat myös voineet pyrkiä osaksi valtavirtaa, mutta johon heidän pääsynsä on rajoitettua sosiaalisen ja taloudellisen ulossulkemisen seurauksena (Seyfang \& Smith 2007).

Kansalaisyhteiskunnan toimijuus kaupunkilaboratoriossa perustuu moninaisiin arvoihin, tarpeisiin ja motivaatiotekijöihin, kuten haluun parantaa kaupunkiympäristöä ja paikallista elämänlaatua, reagoida paikallisiin ongelmiin tai vahvistaa yhteisöllisyyttä ja hyvinvointia (Baccarne ym. 2014). Toimintaa voivat ohjata myös ideologinen sitoutuminen ja halu tarjota vaihtoehtoja vallitseville toimintatavoille (Seyfang \& Smith 2007). Seyfang ja Smith (2007) ovat viitanneet kansalaisyhteiskunnan innovatiivisuudella toimintoihin, jotka yhdistävät kestävyyttä, kokeiluja ja yhteistoimintaa. Me käytämme kestävyyden, innovatiivisuuden ja yhteistoiminnan yhdistelmän kuvaamiseen kestävyyspotentiaalin käsitettä.

Kansalaisyhteiskunnan toimijoiden kestävyyspotentiaali ei useinkaan ole kiinnittynyt teknologisiin innovaatioihin, vaan se on vaikeammin rajautuvaa, kuten sosiaalista ja kulttuurista kestävyyttä tukevaa innovatiivisuutta (Hoogma ym. 2002). Sosiaalisella innovatiivisuudella on lukuisia määritelmiä, mutta tässä tutkimuksessa tarkastelemme sitä ideoina ja aloitteina, joilla pyritään vastaamaan sosiaalisiin tarpeisiin tai tarttumaan sosiaalisiin ongelmiin (ks. NESTA 2008; Vasin ym. 2017). Innovatiivisuus on olennaisesti nykyistä kestävämpien mallien kehittämistä, joiden arvo on ensi sijassa yhteiskunnallista, yksilöllisen sijaan (Phills ym. 2008). Sosiaaliset innovaatiot voivat olla uusia tuotteita, palveluja, prosesseja ja toimintamalleja, joilla vahvistetaan kestävää toimijuutta ja uusien tapojen omaksumista (NESTA 2008; Vasin ym. 2017). Tyypillisiä mekanismeja ovat ideoiden ja arvojen jakaminen vuorovaikutussuhteissa, totuttujen käytäntöjen ja roolien haastaminen, vaihtoehtojen esittäminen sekä voimavarojen yhdistäminen (Phills ym. 2008).

Yhteisötalouden käsite tarjoaa kiinnostavan näkökulman kansalaisyhteiskunnan mahdollisuuksiin kestävyysmurroksen laukaisijana. Yhteisötalous taloudellisen ja sosiaalisen hyvinvoinnin yhdistelmänä on toimijoiden etujen ajamista ja yhteistoimintaa. Se on samalla yrittäjyyden ja toimeentulon hankkimisen tapa niin, että taloudellinen toiminta pysyy ihmislähtöisenä. (Immonen 2006.) Yhteisötalouden näkökulma auttaa havainnollistamaan kestävyyspotentiaalia keskittymällä kollektiiviseen sosiaaliseen innovatiivisuuteen. Innovatiivisuuden ei kuitenkaan tarvitse olla pelkästään sosiaalista, vaan se voi yhdistyä muihin kestävyystavoitteisiin. (Seyfang \& Smith 2007.)

\section{Muutospotentiaalin aktivointi}

Vallitsevan ajattelutavan mukaan innovaatiot saavuttavat muutosvoimansa skaalaamisen kautta (von Wirth ym. 2019; Castán Broto \& Bulkeley 2018). Skaalaaminen tarkoittaa innovaation levittämistä vertikaalisesti eli kontekstista irrottamista, siirtämistä sekä kasvattamista (von Wirth ym. 2019). Kaupungeissa skaalaaminen ilmenee kontrollina ja innovaatiotoiminnan lokeroimisena omaksi sektorikseen (Castán Broto \& Bulkeley 2018). Vaikka muutosvoima yhdistetään usein ylhäältä alaspäin tapahtuvaan ohjaukseen, muutoksia tapahtuu monella muullakin tasolla, eivätkä kaikki niistä ole yhtä näkyviä. Itse asiassa suuri osa kaupunkilaboratorion muutosvoimasta on välillistä eikä perustu innovaatioiden siirrettävyyteen ja kasvattamiseen. Sen sijaan kaupunkilaboratorion toiminta voi itsessään sisältää keinoja kestävyysmurrokseen (mt.). Tämä havainto painottaa innovatiivisuuden kontekstisidonnaisuutta, vuorovaikutteisuutta sekä kestävyyspotentiaalin moninaista, osin tahatontakin ilmenemistä. Seyfang ja Smith 
(2007) ovat kuvanneet tätä sisäsyntyisenä ja horisontaalisesti leviävänä kestävyyspotentiaalina, millä he viittaavat esimerkiksi vaihtoehtoisten, sosiaaliseen ja ekologiseen kestävyyteen kiinnittyvien toimintamallien tarjoamiseen.

Kaupunkilaboratoriolle on ominaista innovatiivisuuden fasilitointi todellisessa ympäristössä. Muutospotentiaali riippuukin siitä erityisestä tilanteesta ja sijainnista, missä kokeilu muodostuu ja missä sitä eletään (Castán Broto \& Bulkeley 2018). Suhde paikkaan on vastavuoroinen, sillä kaupunkilaboratorio myös muovaa paikkaa ja mielikuvia siitä. Toimintaa välittävänä paikkana ja verkostona se sitouttaa osaamista houkuttelemalla uusia yrityksiä ja asiantuntijoita (Baccarne ym. 2014; Ansell \& Miura 2019).

Kestävyysmurroksen mahdollisuutta voidaan tukea vahvistamalla muutokselle suotuisia olosuhteita sekä fasilitoimalla uusia suhteita ja toimintaa, kuten luomalla kestävyydelle uudenlaisia areenoja, tiloja ja yleisöjä (Castán Broto \& Bulkeley 2018; Leminen \& Westerlund 2012). Fasilitointi voidaan myös ymmärtää suhteessa vastaanottajiin, kestävyyspotentiaalin luodessa uudenlaista toimijuutta ja sitouttaessa mukaan uusia toimijoita. Muutos tapahtuu toimijoiden ottaessa haltuunsa uusia arvoja ja toimintatapoja.

Tässä artikkelissa tarkastelemme, kuinka kansalaisyhteiskunnan innovatiivisuutta voidaan aktivoida juurruttamisen (embedding) ja välittämisen (translating) kautta. Juurruttaminen kuvaa sisäsyntyistä kestävyyspotentiaalia ja tarkoittaa innovaation integroimista osaksi vallitsevia toimintatapoja ja rakenteita (Heiskanen ym. 2017; von Wirth ym. 2019). Se on myös kansalaisten sitouttamista kestävämpiin arkisiin käytäntöihin esimerkiksi kouluttamisen ja osallistamisen keinoin (Seyfang \& Smith 2007). Juurruttaminen kuvaa myös rakenteelliseen muutokseen tähtäävää osallistumista, kun yhteistoiminnalla pyritään muuttamaan vallitsevia toimintatapoja, mihin yksilöllä ei yksinään ole resursseja (Seyfang \& Smith 2007). Kansalaisyhteiskunnan toimijat voivat innovatiivisuudellaan osoittaa muutostarvetta sekä toimia muutoksen katalyyttinä luoden aukkoja vaihtoehtoisten ja kestävämpien toimintatapojen valtavirtaistumiselle (Castán Broto \& Bulkeley 2018).

Muutospotentiaalin välittäminen puolestaan tarkoittaa innovatiivisuuden levittämistä hori- sontaalisesti, niin että kansalaisyhteiskunnan kestävyyspotentiaali valtavirtaistuu toiminnan epäsuorien vaikutusten kautta (von Wirth ym. 2019). Välittäminen tapahtuu uudessa paikassa innovaatiota siirtämällä tai jäljentämällä mutta kuitenkin siten, että yhteys alkuperäiseen kontekstiin säilytetään esimerkiksi jaetun institutionaalisen ympäristön tai osin samojen toimijoiden kautta. Kestävyyspotentiaali voi aktivoitua esimerkiksi osallistumisena, joka voimaannuttaa ja vahvistaa osallistujia sekä kerryttää kestävyysmurrosta edistäviä tietoja ja taitoja. Paikallisuus on vahvasti läsnä kestävyyspotentiaalin aktivoitumisessa, joten innovaatioiden omaksumisessa ja soveltamisessa tarvitaan aktiivisia kansalaisia ja demokraattisia paikallisinstituutioita. (Seyfang \& Smith 2007.)

Kaupunkilaboratorioiden tutkimuksessa käsitteellinen työ, joka erittelee toiminnan päämääriä ja vaikuttavuutta, on epäilemättä hyödyllistä, mutta samalla on tärkeää huomata, että erilaiset kestävyyspotentiaalia aktivoivat prosessit toteutuvat myös limittäin. Tähän liittyy tärkeä huomio sisäsyntyisestä muutospotentiaalista: kestävyyden tavoittelun ei tarvitse olla ensisijaista ja jatkuvaa pyrkimystä muutokseen. Potentiaali on läsnä kestävyyttä tukevassa toiminnassa, mutta järjestelmän jäykkyydestä riippuu, voidaanko sillä saavuttaa muutoksia. Seyfangin ja Smithin (2007) mukaan on vaarana, että kansalaisyhteiskunnan toiminnan vaihtoehtoisuus ja kirjavuus haittaavat kestävyyspotentiaalin valtavirtaistamista ja johtavat väliinputoamisen ongelmiin. Lisäksi sosiaalisen innovatiivisuuden välillisiä hyötyjä on vaikeaa mitata, minkä vuoksi ne jäävät usein näkymättömiin. Kaupunkilaboratorioiden innovaatio- ja osallistamisprosessit eivät lopulta olekaan poliittisesti neutraaleja, vaan ne voivat joko haastaa tai vahvistaa vallitsevia tapoja ja toimintamalleja (McCrory ym. 2020). Lisäksi vääjäämättä normatiiviset kestävyyden eri puolet tuovat kaupunkilaboratorioihin kestävyysmurroksen määrittelykamppailuiden dynamiikkaa (emt.).

\section{KULTTUURITOIMIJAT HIEDANRANTAA LUOMASSA}

Tutkimuksen tuloksena esitämme, että kulttuuritoimijoiden muutosvoima tulee Hiedanrannassa esiin kolmella tavalla. Ensimmäinen näkökulma 
käsittelee sitä, kuinka kulttuuritoimijat vastaavat kaupungin asettamiin odotuksiin ja vuorovaikuttavat alueen muiden toimijaryhmien kanssa. Toinen ja kolmas näkökulma - kestävyyspotentiaalin moninaisuus ja sen aktivoiminen - perustuvat kulttuuritoiminnan sisäsyntyisesti kehittyvään kestävyyteen, jota taustoitimme edellisessä luvussa.

\section{Kulttuuritoimijoiden roolit ja yhteistoiminta}

Artikkelin ensimmäinen kontribuutio liittyy kulttuuritoimijoiden toimijuuteen kaupunkilaboratoriossa sekä toimijasektorien rajat ylittävään yhteistoimintaan. Hiedanrannan kehityksen alkumetreistä saakka Tampereen kaupunki on erottanut alueen toiminnot kahteen pääryhmään. Muuntautuva Hiedanranta (aik. Väliaikainen Hiedanranta) viittaa kulttuuritoimintoihin ja käsityöläisiin, kun taas Innovaatioiden Hiedanranta toimii 'kehitysalustana' alueen innovatiivisille yritystoimijoille ja kiertotalouden tutkimuksellisille kokeiluille (Innovaatioiden Hiedanranta 2020). Tarkempi analyysimme Hiedanrannan kehityksestä kuitenkin osoitti, että kulttuuritoimijat ovat muodostaneet suhteita myös innovaatiotoimijoihin, eikä jaottelu kahden ryhmän välillä ole selvärajainen.

\section{Erontekoa toimijasektorien välillä}

Tampereen kaupunki on tunnistanut Hiedanrannan kulttuuritoimintojen tarjoamat mahdollisuudet kehittää aluetta. Ne liittyvät etenkin kaupunginosan tunnetuksi tekemiseen ja elävöittämiseen, kun tapahtumat, harrastusmahdollisuudet, työpajat ja taide houkuttelevat paikalle kaupunkilaisia ja luovat alueen imagoa (Ohjelmasuunnitelma 2019). Luova ilmapiiri houkuttelee myös aloittelevia yrityksiä ja kokeiluja, sitouttaen paikkaan osaamista ja innovatiivisuutta. Alueen elävöittäminen kulttuuritoiminnalla kuvaa luovan toiminnan ja paikan välisen suhteen vastavuoroisuutta, kaupunkilaboratorion muovatessa paikkaa ja mielikuvia siitä. (ks. Baccarne ym. 2014; Ansell \& Miura 2019.) Kulttuuritoimijoiden rooli uuden kaupunginosan elävöittämisessä on ylhäältä päin annettu, ja se on kirjattu toimijoiden vuokrasopimuksiin. Vuokralaisina kulttuuritoimijat sitoutuvat esimerkiksi osallistumaan alueen tapahtumiin, pitämään avoimia ovia työtiloissaan tai vaihtoehtoisesti tuottamaan tapahtumia, joiden kävijämäärä täyttää asetetut vuositavoitteet.

Tässä kaupungin osoittamassa tehtävässä kulttuuritoimijat ovat onnistuneet verrattomasti. Heidän toimintansa on vaikuttanut olennaisesti alueen näkyvyyden, houkuttelevan paikkaidentiteetin ja kestävyystarinan syntymiseen. Hiedanranta tarjoaa kestävyysmurrokselle symbolisen sijainnin ja vaikuttaa jo kehitysvaiheessa yli rajojensa. Onnistuminen yhdessä strategiassa todennäköisesti edistää kaupunkilaboratorion muidenkin tavoitteiden toteuttamista (von Wirth ym. 2019), joten tässä mielessä kulttuuritoimijat ovat Hiedanrannan tärkein toimijaryhmä.

Alueen toimijoiden jaottelu erillisiin sektoreihin kohdistaa kuitenkin kulttuuritoimijoihin ja innovaatiotoimijoihin erilaisia odotuksia ja asettaa heidät toisinaan eriarvoisiin asemiin. Kulttuuritoimijoilta esimerkiksi odotetaan joustoa ja osallistumista alueen tapahtumiin, mutta samat odotukset eivät haastateltavien mukaan koske alueen innovaatiotoimijoita. Tämä kuvaa kulttuuritoimijoille annettua roolia Hiedanrannan elävöittämisessä, kun selkeämmin yritystoimintaa harjoittavat toimijat voivat keskittyä omaan työhönsä ilman jatkuvaa velvoitetta esitellä toimintaansa. Kulttuuri- ja innovaatiotoimijoille on alueella järjestetty erilliset tapaamisensa, mikä viestii kaupungin haasteista tunnistaa sektorirajat ylittävän yhteistoiminnan hyötyjä. Kulttuuritoimijat kokevatkin Hiedanrannan yritysten ja tutkimuksen olevan oma kokonaisuutensa, johon heidän ei haluta kuuluvan. Innovaatiotoiminnan lokeroiminen omaksi sektorikseen on kuitenkin tyypillistä kontrollihakuiselle skaalautumiselle, joka dominoi kestävyysinnovaatioita (vrt. Castán Broto \& Bulkeley 2018).

"Välillä tuntuu, että kokouksissa käy vaan tämmöset epätoimijat. Ne jotka tekee kiinnostavaa kestävää kehitystä, tutkii nollakuitua ja kaiken maailman liemiä, tekee biohiiltä tai muuta suurempaa, ne tekee duunejaan. Ei niitten tarvii osallistua tällaisiin kaiken maailman pilipalihommiin." $\mathrm{H} 1$ 


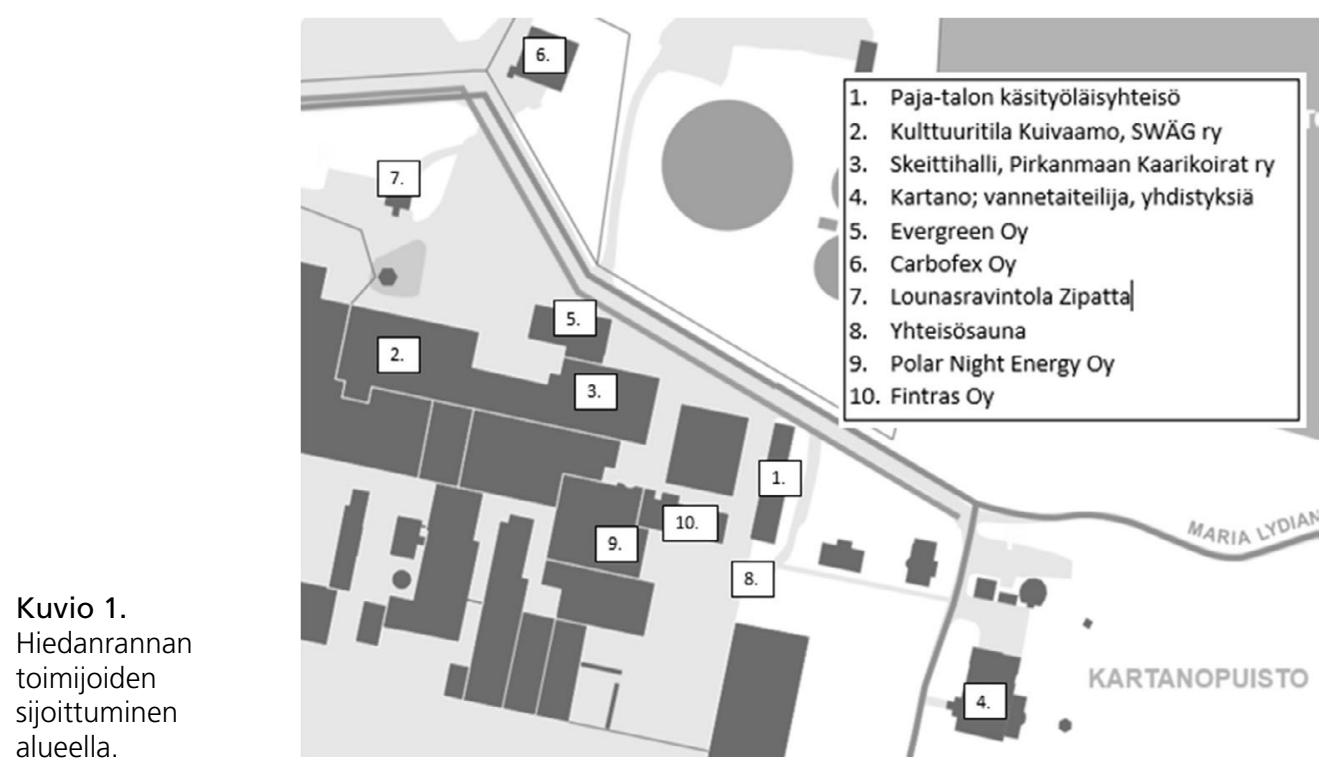

Hiedanrannan kulttuuritoiminta ei kuitenkaan todellisuudessa ole yritys- ja innovaatiotoiminnasta irrallista, vaan lähes kaikkien haastateltavien toimintaan on sekoittunut yrittäjyyttä: kulttuuritoimijoihin niputetut käsityöläiset ovat yksityisyrittäjiä, harrastetoimijat ovat tehneet intohimostaan itselleen ammatin, ja monet työllistävät itsensä lisäksi myös ystäviään. Tunnistimme Hiedanrannan kulttuuritoiminnassa paljon yhteisötalouden piirteitä sosiaalisten tavoitteiden ohjatessa yritystoimintaa (ks. Immonen 2006). Toimijoiden lokerointi heikentää kuitenkin kulttuuritoimijoiden mahdollisuuksia kehittyä ja tehdä yhteistyötä yli sektorirajojen. Usean haastateltavan mukaan eronteko aluetta elävöittävän kulttuurin ja teknisen innovaatiotoiminnan välillä saa mahdolliset yhteistyökumppanit ja asiakkaat aliarvioimaan heidän ammattimaisuuttaan. Erityisesti kulttuuritoimintaa leimannut väliaikaisuus loi negatiivisia mielleyhtymiä.

"Kun me ollaan 4. sektorin toimija, niin meitä kattoo jotkut yrittäjätkin niin että ollaan vaan yhteisö, joka skeittaa ja harrastaa. Mut tosiasiassa se on monen työpaikka ja on siinä bisnestäkin. Ei se oo niin yksinkertaista enää..." $\mathrm{H} 10$

\section{Yhteistoimintaa rajapinnoilla}

Hiedanrannan rosoiset tehdasrakennukset tarjoavat kulttuuritoimijoille paikan toteuttaa itseään. Kulttuuritoimijat ovat vahvistaneet toimintaedellytyksiään järjestäytymällä ja verkostoitumalla, esimerkiksi perustamalla yhdistyksen. Kulttuuritoimijat tekevät yhteistyötä pääasiassa keskenään, mitä osaltaan selittävät tilojen jakamisen kautta syntyvät arkiset kohtaamiset. Toimijoiden läheinen sijainti on synnyttänyt kuitenkin myös sektorirajat ylittävää yhteistoimintaa (Kuvio 1). Hiedanrannan innovatiivisista yrityksistä erityisesti biohiiltä jalostava Carbofex Oy on tehnyt monipuolista yhteistyötä alueen kulttuuritoimijoiden kanssa. Yritys on ostanut palveluita Hiedanrannan kulttuuritoimijoilta sekä osallistunut alueella käynnissä oleviin projekteihin tuomalla yhteiseen käyttöön osaamistaan, tuotteitaan ja tuotannon sivuvirtojen ylijäämää. Yhteistyö on saanut ajan kanssa uusia muotoja, kun viimeisimpänä Hiedanrannan vannetaiteilija keksi testata Carbofexin hiiltä taiteen tekemiseen. Rullalautailuyhdistys Kaarikoirat ry:n ja vertikaaliviljelyä harjoittavan Evergreen Farm Oy:n välillä oli Hiedanrannan alkuvuosina tiivistä yhteistyötä, kun skeittaajien rakennustaidot pääsivät käyttöön yrityksen viljelylaitoksen rakentamisessa. Pienet ja arkiset teot ovat kuitenkin yleisimpiä yhteistoiminnan muotoja, kun 


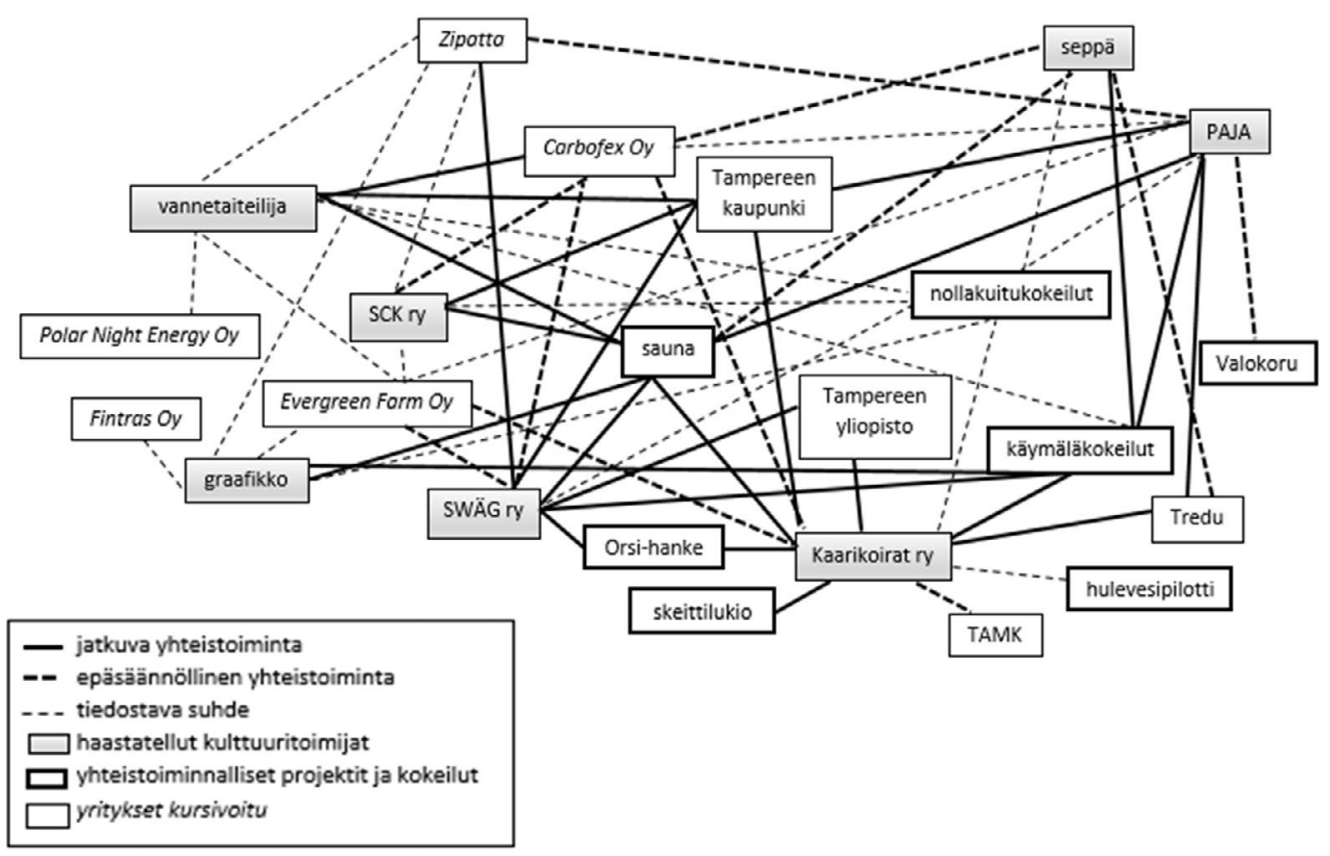

Kuvio 2. Hiedanrannan kulttuuritoimijoiden näkemys heidän suhteistaan alueen muihin toimijoihin.

toimijat ostavat toisiltaan tuotteita ja palveluita ja lainaavat toisilleen työkaluja.

Kaikki Hiedanrannan kulttuuritoimijat ovat vuokrasuhteessa Tampereen kaupunkiin. Moni toimijoista on myös tiiviimmässä yhteistyössä kaupungin kanssa esimerkiksi tilojen kehittämisen tai tapahtumien järjestämisen kautta. Osa kulttuuritoimijoista tekee yhteistyötä myös Hiedanrannassa sivutoimintaa harjoittavien ammattiopisto Tredun ja Tampereen ammattikorkeakoulun kanssa. Yhteistyö oppilaitosten kanssa on hyvin monipuolista: seppä on hitsannut ammattiopiston hajonneen lumiauran kuntoon, Kaarikoirat ry toimi harjoittelupaikkana kiinteistönhuollon opiskelijalle, ja Pajan käsityöläisyhteisön uudet nettisivut valmistuivat ammattikoulun opiskelijatyönä. Yhteistyö perustuu toimijoiden ammattitaitoon ja osaamiseen, mutta se on myös esimerkiksi ajatusten vaihtoa yrittäjyydestä.

Kuvio 2 kuvaa kulttuuritoimijoiden suhteita Hiedanrannan yritysten, kokeilujen, tutkimushankkeiden ja oppilaitosten kanssa. Vuorovaikutussuhteet on tulkittu haastateltujen kulttuuritoimijoiden näkökulmasta, eivätkä eri osapuolet välttämättä näe näitä suhteita samalla tavalla. Epäsäännöllinen yhteistoiminta kuvaa kertaluonteista palvelun tai tuotteen ostamista tai lainausta sekä jo päättynyttä yhteistoimintaa. Jatkuva yhteistoiminta on aktiivista työsuoritusten vaihdantaa tai osallistumista alueen projekteihin tai kokeiluihin. Kuviossa näkyvät heikoimmat suhteet puolestaan kuvaavat, kuinka haastateltavat ovat muista toimijoista tietoisia, mutta eivät ole ryhtyneet heidän kanssaan aktiiviseen kanssakäymiseen. Kuviossa ovat edustettuina vain ne toimijat ja projektit, jotka haastateltavat mainitsivat. Taulukko 1 (luku 2) esittelee kuvion toimijoita tarkemmin. Kuvion yksinkertaistamiseksi olemme jättäneet sen ulkopuolelle kulttuuritoimijoiden keskinäiset suhteet.

Kaikkiaan kuvio 2 tarjoaa havainnollistuksen Hiedanrannan kaupunkilaboratorion systeemisestä luonteesta, mutta silti se on vain tilannekuva yhdestä rajoitetusta näkökulmasta. Kuvio jättää näkyvistä ison osan alueen toimijasuhteista eikä se myöskään tuo esiin kanssatoimijoiden sisäistä moninaisuutta. Esimerkiksi Tampereen kaupungin ja Tampereen yliopiston toimijuus alueella on varsin monisäikeistä. Toisaalta kuvio 
havainnollistaa juuri haastateltujen kulttuuritoimijoiden ymmärrystä Hiedanrannan muista toimijaryhmistä; heidän puheessaan Tampereen kaupunki pelkistyi usein yhdeksi yhtenäiseksi toimijaksi.

Edellä mainitut kuvioon 2 liittyvät löydöksemme kyseenalaistavat monesti esitetyn ajatuksen kaupunkilaboratorioiden kahdesta erillisestä toimintalinjasta sosiaalisten ja teknologisten innovaatioiden välillä (esim. Sengers ym. 2019). Hiedanrannassa kulttuuritoimijat eivät rajoitu paikan elävöittämiseen ja brändäämiseen tai kulttuurin ja taiteen saavutettavaksi tekemiseen, eivätkä he myöskään pelkisty sisäänpäin kääntyneiksi kansalaistoimijoiksi, jotka tuottavat sosiaalisia innovaatioita. He myös kehittävät uutta kaupunginosaa ja sen kestäviä teknologiaratkaisuja yhdessä kaupungin, yritysten ja tutkimuslaitosten kanssa (kuvio 2). Kulttuuritoimijat ovat esimerkiksi osallistuneet aktiivisesti urbaania ravinnekiertoa tukevien käymälöiden kehittämiseen, joita pilotoidaan heidän toimitiloissaan. Vaihtoehtoiset käymälät ovat vielä kehitysvaiheessa, joten kokeilun arki pulmineen on jäänyt tehdaskiinteistöissä työskentelevien kulttuuritoimijoiden harteille. Kulttuuritoimijoiden rooli käymäläkokeiluissa on näin ollen laajentunut käyttäjistä ja testaajista kokeilun ylläpitämiseen ja yhteiskehittämiseen. Löydöksemme kuvaa innovatiivisuuden kontekstisidonnaisuutta ja vuorovaikutteisuutta sekä osin suunnittelematonta ilmenemistä (vrt. Castán Broto \& Bulkeley 2018).

Toinen tutkimuslöydöksemme on, että vuorovaikutussuhteet Hiedanrannassa ovat kehittyneet odotettua monipuolisemmiksi, mikä vahvistaa kaupunkilaboratorion systeemistä luonnetta (ks. von Wirth ym. 2019). Toimijoiden monimuotoisuus, keskinäinen läheisyys ja vuorovaikutus edistävät keksimisen ja oppimisen prosesseja toimijaryhmien välillä. Analyysissa huomiomme kiinnittyi vahvuudeltaan ja intensiteetiltään erilaisiin vuorovaikutussuhteisiin ja kulttuuritoimijoiden osittaiseen kytkeytymiseen kaupunkilaboratorioon, jota havainnollistavat kolme viivatyyppiä kuviossa 2 . Tämä on kiinnostavaa Hiedanrannan tulevan kehityksen kannalta, sillä tämän kaltaiset kaupunkilaboratorion ominaisuudet voivat lisätä toimijoiden valmiuksia yhteiskehittämiseen (Puerari ym. 2018) ja vahvistaa kaupunkilaboratorion kykyä säilyttää elinvoimansa muutostilanteissa (ks. Scheffer ym. 2012). Yhteistoiminnan muodot ovat muuttuneet ajan myötä, ja aktiivisuuden asteissa on eroja toimijoista ja ajankohdasta riippuen.

Edellä esitellyt tulokset osoittavat, että laaja, sektorirajat ylittävä yhteistoiminta on tärkeää tunnistaa kaupunkilaboratorioiden hallinnassa ainakin kahdesta syystä: (1) kaupunkilaboratorioiden rajat liikkuvat, kun toimijat, sosiaaliset suhteet ja toiminnot määrittävät niitä alati uudelleen, ja (2) jos kiinnitetään huomiota vain tärkeimmäksi koettuun toimintalinjaan kuten taloudellisen arvonluonnin prosessiin, kaupunkilaboratorion muut toimijaryhmät saattavat jäädä havaitsematta, vaikka ne olisivat elintärkeitä sen elinvoimaisuudelle ja kyvylle uudistaa kaupunkia.

\section{Kestävyyspotentiaalin moninaisuus}

Toinen kontribuutiomme liittyy kestävyyspotentiaalin selventämiseen, jota ilmentävät toimijoiden monikerroksiset motiivit. Itsensä ja mahdollisella kumppaneidensa työllistämisellä toimijat pyrkivät esimerkiksi tuomaan vaihtoehtoja vallitseville työnteon, tuotannon ja kuluttamisen tavoille. Toisaalta yrityshenkisten kulttuuritoimijoiden tavoitteena on tehdä kannattavaa liiketoimintaa, mikä tukee heidän muita päämääriään, kuten harrastuslajin saavutettavuutta. Liiketoiminnallisten ja sosiaalisten tavoitteiden yhdistelmä yhteisötalouden muotona voi tarjota tukea muutoksille ja vahvistaa kestävyysmurrosta sisältäpäin (Seyfang 2006). Tarkastelemme seuraavaksi Hiedanrannan kulttuuritoiminnan kestävyyttä yhteisötalouden näkökulmasta. Tämä auttaa selventämään kestävyyspotentiaalia sekä kyseenalaistamaan innovatiivisuuden rajoittumisen markkinatoimintaan.

\section{Hyvinvoinnin lisääminen}

Kestävyyspotentiaalin taustalla vaikuttavat kulttuuritoimijoiden pehmeät arvot. Näitä ovat esimerkiksi hyvinvointi, kulttuuri, matalan kynnyksen osallistumismahdollisuudet, yhdessä tekeminen sekä yhteisöllisyys. Pehmeät arvot tukevat paikallisyhteisöä, ja niillä on myös laajempia yhdenvertaisuutta ja hyvinvointia edistäviä vaikutuksia. Kulttuurilla ja taiteella kulttuuritoi- 
mijat haluavat yhdistää ihmisiä, inspiroida, herätellä luovuutta sekä kannustaa itse tekemiseen.

Haastateltaville oli tärkeää, että taide ja kulttuuri ovat Hiedanrannassa vahvasti esillä ja että niiden kokeminen on tehty helpoksi. Kulttuuritoimijat ovat edistäneet kulttuurin ja taiteen saavutettavuutta ja monipuolisuutta laajentamalla toimitilojaan, parantamalla alueen toimintamahdollisuuksia sekä järjestämällä avoimia tapahtumia. Suuri osa alueen tapahtumista on ikärajattomia, maksuttomia ja ohjelmaltaan monipuolisia, mikä houkuttelee laajasti yleisöä. Tehtaiden seiniä koristavat muraalit puolestaan tuovat taiteen esille myös heille, jotka eivät vieraile gallerioissa. Avoimilla harrastusvuoroilla yhdistykset pyrkivät madaltamaan osallistumisen kynnystä. Harrastamisen nähdään lisäävän hyvinvointia, sillä se on keino rentoutua, pitää yllä suhteita ja kuulua ryhmään.

”...sen lisäks että saadaan tästä välillä palkkaa, niin onhan tässä yhteisö, joka helpottaa meidän kaikkien elämää tavalla tai toisella." H8

Hiedanrannan yhdistykset ja ryhmät toimivat yhteisöinä, jotka tarjoavat tukea jäsenilleen. $\mathrm{Ne}$ edistävät harrastusmahdollisuuksia jakamalla tietoa apurahoista, avoimista työpaikoista ja tapahtumista. Osa ryhmistä on tietoisesti käyttänyt yhdistystoimintaa tukiverkon rakentamiseen voidakseen huolehtia jäsentensä hyvinvoinnista. Mahdollisuus palkkatyöhön yhdistyksessä kannattelee jäseniä heikoilla hetkillä, ja samalla työskentely yhdistyksessä toimii väylänä, jonka kautta voidaan hankkia osaamista ja päästä myöhemmin kiinni muihin töihin. Tarjoamalla mielekästä tekemistä yhdistystoiminta voi ehkäistä nuorten syrjäytymistä ja ylipäätään tukea jäsenten jaksamista ja selviytymistä muilla elämän osa-alueilla.

\section{Korjaaminen ja hävikin minimointi}

Kiertotalousajattelu ilmenee tilojen uuskäytön lisäksi selvimmin Pajan käsityöläisten ekologista kestävyyttä ajavina tavoitteina. Hiedanrannassa työskentelee useita korjaamiseen ja entisöintiin erikoistuneita ammattilaisia, kuten seppä ja verhoilija, jotka työssään edistävät jätevirran minimointia korjaamalla ja kierrättämällä vanhoja tuotteita. Korjauspalveluilla he haluavat piden- tää tuotteiden käyttöikää ja samalla kannustaa kestävämpien tuotteiden valintaan. Kaikkia haastateltuja käsityöläisiä yhdisti pyrkimys päästä eroon kertakäyttöisyydestä. Oman tuotteen halutaan kestävän aikaa, oli kyse sitten painotuotteesta, laukusta tai huonekalusta.

\section{"Jos sä ostat tuotteen, joka kestää kolme vuotta, sit se heitetään kaatopaikalle tai tien viereen ja haetaan uus. Samantyyppisiä materiaaleja kuluu korjaamiseen, mutta on se silti järke- vämpää kuin jatkuvasti ostaa heikkolaatuisia tavaroita." $\mathrm{H} 1$}

Hiedanrannan käsityöläiset tarjoavat vastuullisemman vaihtoehdon kuluttamiseen hyödyntämällä työssään kierrätys- ja hävikkimateriaaleja. Moni haastateltava painotti, että tuotteen pitkän iän ohella sillä on oltava merkitys asiakkaalle. Toiminimiyrittäjä pystyy isoa yritystä joustavammin räätälöimään tuotteet asiakkaiden toiveiden mukaan, ja asiakkaat luultavasti pitävät parempaa huolta toiveidensa mukaan räätälöidystä työstä kuin massatuotetusta halpatuotteesta. Vuosien kuluessa toiminnan ekologiset tavoitteet olivat kuitenkin siinä määrin arkipäiväistyneet, ettei moni haastateltavista nostanut niitä esiin aktiivisesti, vaikka samat tavoitteet vaikuttivatkin edelleen toiminnan taustalla.

\section{Kestävyyden levittämisen tapoja}

Kolmas kontribuutiomme kiinnittyy Castán Broton ja Bulkeleyn (2018) esittämään argumenttiin kaupunkilaboratorion muutosvoimasta välillisenä ja monitasoisena. Vaikka muutosvoima yhdistetään usein ylhäältä alaspäin suuntautuvaan ohjaukseen ja innovaatioiden kasvattamiseen, tapahtuu kestävyyspotentiaalin aktivoimista myös muilla, usein näkymättömiin jäävillä tasoilla. Tarkastelumme osoittaa, ettei Hiedanranta ole usein toistetun ihannekuvauksen mukainen, skaalaamalla muutosvoimansa saava innovaatioalusta. Hiedanrannan kulttuuritoiminnan kestävyyspotentiaali on sen sijaan sisäsyntyistä ja horisontaalisesti levitettävää (ks. Seyfang \& Smith 2007). Tarkastelemme seuraavaksi kulttuuritoiminnan uudistavaa voimaa juurruttamisen ja välittämisen kautta (von Wirth ym. 2019). 
Suurimmalla osalla Hiedanrannan kulttuuritoimijoista ei ole avoimesti ilmaistua vahvaa pyrkimystä laajaan kestävyysmurrokseen, vaan kestävyyspotentiaali sisältyy arkiseen, osin tiedostamattomaankin toimintaan. Joidenkin haastateltavien kohdalla havaitsimme kuitenkin pyrkimystä haastaa vallitsevia tapoja muuttamalla työkulttuuria, kaupunkitilaa ja kaupunkikehittämisen käytäntöjä. Nämä toimijat pyrkivät myös selkeimmin valtavirtaistumaan. Tässä tulevat kuitenkin eteen väliinputoamisen haasteet. Koska Hiedanrannan kulttuuritoiminta on sekotus innovatiivista yritystoimintaa ja sosiaalisia tavoitteita, se ei istu helposti ylhäältä päin annettuihin kategorioihin. Toiminnan moninaisuus ja sosiaalisen innovatiivisuuden mittaamisen haasteet heikentävät näin kestävyyspotentiaalin valtavirtaistamista (Seyfang \& Smith 2007).

\section{Osallisuus ja yhteistyö muutoskatalyytteinä}

Hiedanrannan kulttuuritoiminnan kestävyyspotentiaali aktivoituu osallistumisen kautta. Osallisuus on hyvinvoinnin ohella yksi sosiaalisen kestävyyden kulmakivistä, ja sen voima kestävyysmurroksessa perustuu toimijuuden vahvistumiseen ja tietoisuuden nousuun. Samalla osallisuuden kautta syntyvä tunne omistajuudesta edistää mobilisoitumista ja toimintatapojen muutosta (ks. Castán Broto \& Bulkeley 2018). Moni haastateltava tunnisti itsetekemisen ja osallistumismahdollisuudet avaimina tiedostavan kansalaisuuden kehittymiseen: kulttuuri ja taide tarjoavat taukoja kiireiseen työelämään, ja ne voivat aktivoida ajattelua eri tavoin kuin arkinen työelämä. Tiedostavat kansalaiset puolestaan voivat levittää kestävyyttä sosiaalisten suhteidensa kautta aina uusiin ympäristöihin (Seyfang \& Smith 2007).

”..mua kiinnostaa paljon, että ihmiset löytäis omia vahvuuksiaan. Jokaisella meillä on keho, jonka rajoissa liikkuminen tuo mielihyvää. Toivon, että ihmiset liikkuis ja löytäis vahvuutensa luovassa työssä. Tai ei sen tarvi olla työtä, se voi olla harrastus." H9

Hiedanrannan kulttuuritoimijat tukevat toimintansa jatkumista alueella yhdistämällä voimavarojaan. Yhdistymällä kulttuuritoimijat pyrkivät saavuttamaan toiminnalleen huomiota ja tuovat esiin kestävyyspotentiaaliaan. Seyfang ja Smith (2007) ovat kuvanneet muutokseen tähtäävää osallistumista juurruttamisella: yhteistoiminnan tavoitteena on muuttaa vallitsevaa järjestystä; tässä tapauksessa luoda tilaa ja toimintaedellytyksiä kulttuuritoiminnan jatkumiselle, mihin toimijoilla erillään ei olisi yhtäläisiä resursseja. Yhteistoiminta osoittaa samalla muutostarvetta sosiaalisesti ja kulttuurillisesti kestävämmän kaupungin kehittämiseen, joka voi toimia muutoksen katalyyttinä.

\section{Esimerkkinä toimiminen ja ideointi kestävyyttä levittämässä}

Kulttuuritoimijat kehittävät Hiedanrantaa paikallisesti muovaamalla omaa toimintaympäristöään. Moni heistä ilmaisi olevansa kiinnostunut vaikuttamaan myös laajemmin kestävän kaupunkikehityksen käytäntöihin, joiden pilotoinnille Hiedanranta luo potentiaalisen ympäristön. Kulttuuritoimijoita turhautti alueen kehittämisen väliaikaisuus, ja he toivoivat kaupungilta rohkeutta antaa kulttuuritoiminnan kehittyä ajan kanssa. Vaihtuvien viranhaltijoiden ja päättyvien tutkimushankkeiden rinnalla Hiedanrannan kulttuuritoimijat ovat suhteellisen pysyvä osa kaupunkilaboratoriota, ja heille on kertynyt paikallista tietoutta. Tämä löydös tukee käsitystä kulttuuritoimijoiden toimijuudesta paikkasidonnaisen kestävyyden edistämisessä (ks. Castán Broto \& Bulkeley 2018). Useat haastateltavat korostivat myös kaupunkilaisten roolia kestävässä kaupunkisuunnittelussa. Tässä kulttuuritoimijat itse ovat keskeisessä asemassa vaikuttamassa Hiedanrannan kehittämisen teemoihin, osallistumalla ja osallistamalla. Näin kestävyyspotentiaalia aktivoidaan toiminnan epäsuorien sosiaalisten vaikutusten kautta.

Kulttuuritoimijat pyrkivät tietoisesti vaikuttamaan mielikuviin kaupungista ja sen julkisista tiloista sekä siihen, millaisille asioille kaupungin kaduilla on tilaa. Totuttujen käytäntöjen haastamista voidaan kuvata horisontaalisena kestävyyspotentiaalin välittämisenä (von Wirth ym. 2019). Välittäminen tapahtuu uudessa paikassa toimintaa jäljentämällä, mutta yhteys alkuperäiseen kontekstiin säilytetään samojen toimijoiden kautta, jotka ovat kerryttäneet tietojaan ja taitojaan Hiedanrannassa. Kulttuuritoimijat tuovat kulttuurin ja taiteen vahvasti esiin Hiedan- 
rannassa, mutta samaan aikaan osalla heistä oli käynnissä projekteja myös muissa kaupunginosissa. Näin he pyrkivät varmistamaan, ettei monipuolinen kaupunkikulttuuri rajoitu vain Hiedanrantaan. Samaa tavoitetta palvelevat Hiedanrannalle tavoiteltu mediajulkisuus sekä ideoiden jakaminen kaupunkikulttuurin mahdollisuuksista.

"Me koitettiin saada viesti perille kaupungin puutarhurille, että Laikunlavan edustaa vois elävöittää tuomalla siihen skeitattavia elementtejä. Se aktivois keskustaa. Nyt on kanssa maalausyhdistyksellä neuvottelut, että me saatais maalauspaikkoja ihan keskustaankin. Että niitä olis muuallakin kuin Hiedanrannassa." H7

Usean haastateltavan työtä ohjasi pyrkimys tarjota vaihtoehto vallitseville työelämän rakenteille ja käytännöille ja tukea näin laajempaa työelämän muutosta. Hiedanrannan yhdistykset haluavat luoda työkulttuuria, joka kannustaa kokeiluihin ja jossa virheistä voidaan oppia. Omalla toiminnallaan kulttuuritoimijat näyttävät esimerkkiä pyrkiessään muuttamaan hierarkkista johtamiskulttuuria yhteisöllisemmäksi ja tasavertaisemmaksi. Heitä yhdisti myös hyvän ja kannustavan työympäristön arvottaminen korkeammalle kuin palkka. Sosiaalisesti kestävä työympäristö vahvistaa niin työntekijöitä kuin työllistäviä yhdistyksiä ja heidän jäseniänsä, jotka voivat välittää kokemuksensa ja oppinsa eteenpäin muihin ympäristöihin. Seyfang ja Smith (2007) ovat nimittäneet tätä kestävyysmurroksen vahvistamiseksi demokraattisten toimintaympäristöjen kautta.

\section{JOHTOPÄÄTÖKSET}

Kaupunkilaboratoriot ovat paikkoja, joissa muovataan, testataan ja kehitetään innovaatioita todellisessa ympäristössä. Innovaatiot eivät kuitenkaan synny tyhiössä, vaan vuorovaikutteisessa suhteessa paikkaan, sen erityispiirteisiin ja toimijoihin. Kaupunkilaboratorio ei myöskään ole pelkkä ajatushautomo, josta putkahtelee ulos ideoita, vaan siinä on myös paljon sisäsyntyistä muutos- ja kestävyyspotentiaalia. Tutkimuksemme lähtökohtana on ollut näkemys, että innovatiivisuus syntyy kaupunkilaboratorion sisällä, josta käsin pyritään vaikuttamaan vallitseviin käytäntöihin. Yhteistoiminnalliseen kaupunkilaboratorioon sitoutuu monipuolista sosiaalista kestävyyttä, minkä tunnistaminen kääntää huomion yritystoimijoista ja teknisistä innovaatioista kansalaisyhteiskunnan toimijoihin.

Olemme esittäneet tutkimustuloksemme kolmen kontribuution kautta, joista ensimmäinen kuvaa kulttuuritoimintaa ja sektorirajat ylittävää yhteistyötä Hiedanrannan kaupunkilaboratoriossa. Toinen kontribuutio selventää kulttuuritoiminnassa ilmenevää kestävyyttä, kun taas kolmas kontribuutio havainnollistaa kestävyyspotentiaalin horisontaalista aktivointia vaihtoehtona skaalaamiseen keskittyvälle tarkastelulle. Kontribuutiomme osoittavat, etteivät kulttuuritoimijat pelkästään luo Hiedanrannan ilmapiiriä, vaan he ovat toisellakin tavalla ratkaisevia kaupunkilaboratorion kehityksessä. Sektorirajat ylittävän yhteistoiminnan kautta kulttuuritoimijat ovat osa toimijaverkostoja. He ovat paitsi innovaatioiden testaajia myös niiden yhteiskehittäjiä, ja luovat uusia osallistumisen käytäntöjä. Toimijuus ei rajoitu luovaan kulttuurityöhön ja käsityöläisyyteen, vaan kulttuuritoimijat edistävät myös yhteisötalouden mukaisia sosiaalisen kestävyyden päämääriä. Aktiivisen toimijuutensa ja monipuolisten suhteidensa ansiosta kulttuuritoimijoilla on kaupunkilaboratoriota uudistavaa voimaa, vaikkakin tämä dynaaminen rooli jää helposti huomiotta.

Kaupunkilaboratorio hajautetun ja verkostoituvan hallinnan perustana nostaa huolta vallankäytöstä ja demokratiasta esimerkiksi silloin, kun kaupunkilaboratorion toimijat yksipuolistuvat jonkin toimijaryhmän yliedustuksen vuoksi (Ansell \& Miura 2019, 265). Hiedanrannan tapauksen analyysi osoittaa, että vinouma toimijakentässä voi olla todellinen tai liittyä tunnistetun toimijuuden rajoittuneisuuteen ja sen arvottamiseen suhteessa asetettuihin tavoitteisiin. Kun julkishallinto siirtyy suorasta ohjauksesta yhteistyöalustojen fasilitointiin, on tarkasteltava uudelleen myös kaupunkilaboratorion toimijuutta, reunaehtoja sekä resurssien jakautumista. Kaupunki voi fasilitoijana ja mahdollistajana tukea kaupunkilaboratorion edellytyksiä ja laajaa vaikuttavuutta, mutta myös rajoittaa niitä (Franz ym. 2015; Ansell \& Miura 2019). Kun kaupunkilaboratorio on kaupallisen yhteiskehittämisen sijaan osa julkishallinnon muutosta, 
kaupungin tulee tukea sen kehitystä avoimena ja laaja-alaisena toimijoiden yhteenliittymänä, jossa monipuolista kestävyyttä arvotetaan tasapuolisesti.

Hiedanrannan kaupunkilaboratorion tarkastelu osoittaa, että nykyinen kiertotalousvisio on kapea: se tunnistaa heikosti sosiaalista innovatiivisuutta ja sulkee ulos monenlaista kestävyyspotentiaalia. Innovatiivisuuden lokerointi kulttuurista erilliseksi sektoriksi yksipuolistaa tunnistettua innovatiivisuutta, ja suuri osa kulttuuritoimijoiden kestävyyspotentiaalista jää tunnistamatta. Samalla kun kulttuuritoimijat tuntevat ulkopuolisuutta innovaatiotoiminnasta, kaikki heistä eivät kuitenkaan edes halua tulla osaksi yhteistyöalustaa, vaan heille on tärkeää pysyä vaihtoehtoisina ja irti kaupungin ohjauksesta tai osallistua vain osittain. Erot osallistujien intensiteetissä ja kytkeytyneisyydessä voivat lisätä kaupunkilaboratorion systeemistä elinvoimaisuutta muuttuvissa olosuhteissa (Scheffer ym. 2012). Näennäisen hallittavuuden sijaan kulttuuritoimintaa tulisikin tarkastella vahvana voimavarana, joka edistää kaupunkilaboratorion toimintaa voimakkaasti muuttuvassa ympäristössä. Toisaalta kulttuuritoimijoiden kokema ulkopuolisuus ja erillisyys saattaa joissain tilan-

\section{LÄHTEET}

Ansell, C. \& Miura, S. (2019). Can the power of platforms be harnessed for governance? Public Administration, 2020, 98, 261-276.

Anttiroiko, A.-V. (2010). Luova kaupunkikehittäminen. Kaupunkikonseptit innovatiivisen kaupunkikehittämisen apuna. Tampereen yliopisto, Alueellisen kehittämisen tutkimusyksikkö SENTE, julkaisu 32/2010.

Anttiroiko, A-V. (2016). City-as-a-Platform: The rise of participatory innovation platforms in Finnish cities. Sustainability, 8, 922.

Baccarne, B., Mechant, P., Schuurman, D. Colpaert, P. \& De Marez, L. (2014). Urban socio-technical innovations with and by citizens. Interdisciplinary Studies Journal 3(4), 143-156.

Bulkeley, H. \& Broto, V. (2013). Government by experiment? Global cities and the governing of climate change. Transactions of the Institute of British Geographers, 38(3), 361-375.

Bulkeley, H., Coenen, L., Frantzeskaki, N., Hartmann, C., Kronsell, A., Mai, L., ... Voytenko Palgan, Y. (2017). Urban Living Labs: Governing teissa olla myös hidastava tekijä ja haitata yhteistyömahdollisuuksia.

Tarvitaan lisää tutkimusta siitä, miten kaupunkilaboratoriot toimivat paikallisena hallinnan siirtymänä ja miten kansalaisyhteiskunnan osallisuutta vahvistetaan näillä foorumeilla. Samalla tulee laajentaa ymmärrystä kestävyysmurroksesta ja sen valtavirtaistamisen keinoista. Lisäksi tarvitaan tutkimusta siitä, miten kansalaistoimijoiden adaptiivisuus ja intensiteetin erot kytkeytyneisyydessä voivat vahvistaa kaupunkilaboratoriota ja sen tavoitteiden saavuttamista.

\section{TUTKIMUKSEN RAHOITUS}

Tätä tutkimusta on rahoittanut Suomen Akatemian yhteydessä toimiva strategisen tutkimuksen neuvosto (rahoituspäätös 320206, hanke CICAT2025).

\section{KIITOKSET}

Kiitämme lehden käyttämiä käsikirjoituksen arvioijia sekä Tampereen yliopiston POLEIStutkimusseminaaria erinomaisista kommenteista.

urban sustainability transitions. Current Opinion in Environmental Sustainability, 22, 13-17.

Castán Broto, V. \& Bulkeley, H. (2018). Realigning circulations. Teoksessa Turnheim, B., Kivimaa, P. \& Berkhout, F. (Eds.), Innovating Climate Governance: Moving Beyond Experiments (s. 69-84). Cambridge: Cambridge University Press.

Corvellec, H., Böhm, S., Stowell, A. \& Valenzuela, F. (2020). Introduction to the special issue on the contested realities of the circular economy. Culture and Organization, 26(2), 97-102.

Frantzeskaki, N., Dumitru, A., Anguelovski, I., Avelino, F., Bach, M., Best, B. \& Rauschmeyer, F. (2016). Elucidating the changing roles of civil society in urban sustainability transitions. Current Opinion in Environmental Sustainability, 22, 41-50.

Franz, Y., Tausz, K. \& Thiel, S. (2015). Contextuality and co-creation matter: A qualitative case study comparison of living lab concepts in urban research. Technology Innovation Management Review, 5(12), 48-55. 
Heiskanen, E., Hyvönen, K., Laakso, S., Laitila, P., Matchoss, K. \& Mikkonen, I. (2017). Adoption and use of low-carbon technologies: Lessons from 100 Finnish pilot studies, field experiments and demonstrations. Sustainability, 9, 847.

Hobson, K. (2016). Closing the loop or squaring the circle? Locating generative spaces for the circular economy. Progress in Human Geography, 40, 88-104.

Hoogma, R., Kemp, R., Schot, J. \& Truffer, B. (2002). Experimenting for Sustainable Transport. The Approach of Strategic Niche Management. London: EF \& NSpon.

Immonen, N. (2006). Yhteisötalous Suomessa, sisäpiirin slangia vai uutta yhteistyön taloutta. Tampere: Tampereen seudun osuustoiminnan kehittämisyhdistys ry.

Ingstrup, M., Aarikka-Stenroos, L. \& Adlin, N. (2020). When institutional logics meet: Alignment and misalignment in collaboration between academia and practitioners. Industrial Marketing Management.

https://doi.org/10.1016/j.indmarman.2020.01.004 (in press)

Innovaatioiden Hiedanranta (2020). Haettu sivulta: https://www.tampere.fi/asuminen-ja-ymparisto/kaupunkisuunnittelu-ja-rakentamishankkeet/innovaatioiden-hiedanranta.html, 3.6.2020.

Karppi, I. \& Vakkuri, J. (2020). Becoming smart? Pursuit of sustainability in urban policy design. Public Management Review, 22(5), 746-766.

Kębłowski, W., Lambert, D. \& Bassens, D. (2020). Circular economy and the city: an urban political economy agenda. Culture and Organization, 26(2), 142-158.

Kettunen P., Heino, H. \& Sankala, I. (2019). Strategioista toiminnaksi? Kestävän kehityksen edistäminen paikallisella tasolla. Focus Localis, 47(1), 26-43.

Korhonen, J., Honkasalo, A. \& Seppälä, J. (2018). Circular economy: The concept and its limitations. Ecological Economics, 143, 37-46.

Krause, R. M., Hawkins, C. V., Park, A. Y. \& Feiock, R. C. (2019). Drivers of policy instrument selection for environmental management by local governments. Public Administration Review, 79(4), 477-487.

Laine, M., Kuoppa, J., Alatalo, E. \& Kyrönviita, M. (toim.) (2017). Ideakilpailun jatkot - Kaupunkilaisten visio tulevaisuuden Hiedanrannasta. Tampereen kaupunki.

Lehtovuori, P., Edelman, H., Rintala, J., Jokinen, A., Rantanen, A., Särkilahti, M. \& Joensuu, T. (2016). Hiedanrannan kehittämisvisio: Tiivis ja intensiivisesti vihreä Tampere City West. Tampere: Tampereen teknillinen yliopisto.

Leino, H. \& Puumala, E. (2020) What can co-creation do for the citizens? Applying co-creation for the promotion of participation in cities. Environment and Planning C: Politics and Space. September 2020. doi:10.1177/2399654420957337

Leminen, S. \& Westerlund, M. (2012). Towards innovation in living labs networks. International Journal of Product Development, 17, 43-59.

Leminen, S., Nyström, A. G., Westerlund, M. \& Kortelainen, M. J. (2016). The effect of network structure on radical innovation in living labs. Journal of Business \& Industrial Marketing, 31(6), 743-757.

Leminen, S., Rajahonka, M. \& Westerlund, M. (2017). Towards third-generation living lab networks in cities. Technology Innovation Management Review, 7(11), 21-35.

McCrory, G., Schöpke, N., Holmén, J. \& Holmberg, J. (2020). Sustainability-oriented labs in real-world contexts: An exploratory review. Journal of Cleaner Production, 277. December 2020. https://www.sciencedirect.com/science/ article/pii/S0959652620332479

NESTA (2008). Social Innovation: New approaches to transforming public services. SI/18, January Policy Briefing.

Nesti, G. (2018). Co-production for innovation: the urban living lab experience. Policy and Society, 37(3), 310-325.

Ohjelmasuunnitelma (2019). Hiedanrannan kehitysohjelma, Tampereen kaupunki. Julkaistu 9.12.2019.

Phills Jr., J.A., Deiglmeier, K. \& Miller, T.D. (2008). Rediscovering social innovation. Stanford Social Innovation Review, 6(4), 34-44.

Puerari, E., De Koning, J. I., Von Wirth, T., Karré, P. M., Mulder, I. J. \& Loorbach, D. A. (2018). Co-creation dynamics in urban living labs. Sustainability, 10(6), 1893.

Scheffer, M., Carpenter, S. R., Lenton, T. M., Bascompte, J., Brock, W., Dakos, V., ... \& Pascual, M. (2012). Anticipating critical transitions. Science, 338(6105), 344-348.

Sengers, F., Wieczorek, A. J. \& Raven, R. (2019). Experimenting for sustainability transitions: A systematic literature review. Technological Forecasting and Social Change, 145, 153-164.

Seyfang, G. (2006). Harnessing the potential of the social economy? Time Banks and UK public policy. International Journal of Sociology and Social Policy, 26(9/10), 430-43.

Seyfang, G. \& Smith, A. (2007). Grassroots innovations for sustainable development: Towards 
a new research and policy agenda. Environmental Politics, 16, 584-603.

Särkilahti, M., Mustajärvi, K. \& Leppänen, S. (2019). Biosuodattimia, hevoshakoja ja viherkattoja - yhdessä oppiminen luontopohjaisten ratkaisujen luomisessa. Alue ja Ympäristö, 48, 20-37.

Tuurnas, S. (2016). The Professional Side of CoProduction. Tampere: Tampere University Press.

Vasin, S. M., Gamidullaeva, L. A. \& Rostovskaya, T. K. (2017). The challenge of social innovation: approaches and key mechanisms of development. European Research Studies Journal, 20(2B), 25-45.

Voytenko, Y., McCormick, K., Evans, J. \& Schliwa,
G. (2016). Urban living labs for sustainability and low carbon cities in Europe: towards a research agenda. Journal of Cleaner Production, $123,45-54$.

Von Wirth, T., Fuenfschilling, L., Frantzeskaki, N. \& Coenen, L. (2019). Impacts of urban living labs on sustainability transitions: mechanisms and strategies for systemic change through experimentation. European Planning Studies, 27(2), 229-257.

Williams, J. (2019). Circular Cities. Urban Studies, 56(13), 2746-2762.

Zeemering, E. S. (2018). Sustainability management, strategy and reform in local government. Public Management Review, 20(1), 136-153. 